\title{
ANALISIS POTENSI BRIKET BIO-ARANG SEBAGAI SUMBER ENERGI TERBARUKAN
}

\section{ANALYSIS OF POTENCY OF BIOCHARCOAL BRIQUETTES AS A RENEWABLE ENERGY SOURCE}

\author{
Widya Fitriana ${ }^{1 \bowtie}$ dan Wetri Febrina ${ }^{2}$ \\ ${ }^{1}$ Agribisnis, Fakultas Pertanian, Universitas Andalas \\ ${ }^{2}$ Teknik Industri, Sekolah Tinggi Teknologi Dumai

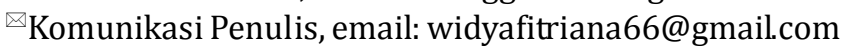 \\ DOI:http://dx.doi.org/10.23960/jtep-lv10i2.147-154 \\ Naskah ini diterima pada 14 Maret 2021; revisi pada 21 Maret 2021; \\ disetujui untuk dipublikasikan pada 6 April 2021
}

\begin{abstract}
The research aimed to examine the potential of bio-charcoal briquettes as solid fuel using a SWOT analysis approach, by comparing them with non-briquette solid fuels. The SWOT method examines internal factors (IFAS) and external factors (EFAS). The research was conducted at a wood charcoal produces located at Dumai City, Riau. Data retrieval was carried out by means of observation and interview with the owner and workers. Including production data, marketing, problems faced during production, promotion and sale, product added value, product shortages and weaknesses, competitor data and opportunities in business development. The results of this research indicated that the advantages of briquette products was renewable, cheap, raw materials environmentally friendly, ease of packaging, cleanliness in the production process and efficiency in transportation. The disadvetages was less popular, requires a combustion furnace and fluctuating heat. The ooportunity was that the need for charcoal continues to increase, especially for restaurants and micro small industry. This research was recommend the importance of public policies related to the promotion and socialization of the use of bio-charcoal briquettes as a source of clean energy that is economical and environmentally friendly.
\end{abstract}

Keywords: bio-charcoal briquettes, renewable energy, SWOT analysis

\begin{abstract}
ABSTRAK
Penelitian ini bertujuan untuk mengkaji potensi briket bioarang sebagai bahan bakar padat dengan pendekatan analisis SWOT, dengan membandingkannya dengan bahan bakar padat non briketMetode SWOT yang digunakan mengkaji faktor internal (IFAS) dan faktor external (EFAS).Tempat penelitian adalah sebuah CV yang merupakan produsen arang kayu di Kota Dumai, Riau.Pengumpulan data menggunakan metode pengamatan dan wawancara terhadap pemilik usaha dan pekerja. Meliputi data produksi, pemasaran, kendala yang dihadapi saat produksi, kendala yang dihadapi saat pemasaran produk, nilai lebih produk, kekurangan dan kelemahan produk, data pesaing dan peluang dalam pengembangan usaha.Hasil penelitian menunjukkan bahwa potensi pengembangan produk briket bioarang dari bio-massa sebagai sumber energi alternatif adalah kuat dan berpeluang. Kelebihan briket bioarang adalah bersifat renewable, bahan baku murah, ramah lingkungan, kemudahan dalam pengepakan, kebersihan dalam proses produksi dan efisien dalam pengangkutan. Kelemahannya adalah kurang popular, membutuhkan tungku pembakaran dan nilai kalor yang fluktuatif.Peluangnya adalah kebutuhan arang yang terus meningkat, terutama untuk restoran/rumah makan dan UMKM.Hasil penelitian ini merekomendasikan perlunya public policy terkait promosi dan sosialisasi penggunaan briket bioarang sebagai salah satu sumber energi bersih yang ekonomis dan bersahabat denganlingkungan.
\end{abstract}

Kata kunci: analisis SWOT, briket bioarang, energi terbarukan 


\section{PENDAHULUAN}

Seiring meningkatnya jumlah penduduk dan pertumbuhan ekonomi, kebutuhan akan energi semakin meningkat setiap harinya. Meskipun perkembangan teknologi yang mendukung penghematan pemakaiaan energi fosil terus dikembangkan, saat ini energi fosil masih menempati posisi utama dalam penyediaan kebutuhan energi di dunia.Sayangnya menipisnya cadangan energi fossil dunia menuntut perhatian dari kalangan akademisi dan politisi untuk melakukan langkah-langkah penghematan energi dan alih sumber energi.Beberapa sumber energi alternatif yang ditawarkan meliputi energi matahari, energi panas bumi, energi air, energi angin, danbiomassa.Pemanfaatan energi alternatif ini diharapkan dapat mengatasi kebutuhan energi dunia yang semakin meningkat, lebih ramah lingkungan dan bersifat renewable (terbarukan).

Bahan bakar berdasarkan wujudnya terbagi atas bahan bakar padat (arang, batubara, biomassa), bahan bakar cair (bensin, solar, biosolar, avtur, kerosene, dan lain-lain), dan bahan bakar gas (LPG, LNG, biogas).Sebagian besar bahan bakar yang dipakai saat ini bersumber dari fossil yang persediannya semakin menipis.Briket bioarang memiliki potensi besar sebagai bahan bakar alternatif jenis bahan bakar padat.Bahan bakunya melimpah sehingga sangat potensial dikembangkan di daerah-daerah marjinal yang penduduknya masih jarang dan topografi daerahnya sulit dijangkau armada pendistribusian bahan bakar milik pemerintah (Pertamina)(Miharja, 2016).

Sumber energi alternatif yang dapat diperbaharui di Indonesia tersedia cukup banyak diantaranya adalah yang berasal dari biomassa atau bahan-bahan limbah organik. Beberapa biomassa yang memiliki potensi yang cukup besar yang telah diteliti untuk pengembangan bio-briketantara lain berasal dari tempurung kelapa (Eka Putri dan Andasuryani, 2017), kotoran sapi (Mislaini dan Anugrah, 2010), sampah organik (Febrina, 2018)tongkol jagung (Kalsum, 2016)dan serbuk kayu (Surest dan Afif, 2011). Sumber bio-massa yang berasal dari limbah pertanian/perkebunan selama ini masih banyak yang belum diolah secara optimal bahkan ada yang dibuang begitu saja(Arni et al,, 2014).

Untuk meningkatkan nilai ekonomisnya, biomassa dapat diolah menjadi briket arang.Briket arang merupakan bahan bakar padat yang mengandung karbon, mempunyai nilai kalori yang tinggi dan dapat menyala dalam waktu yang lama.Bio-arang adalah arang yang diperoleh dengan membakar biomassa kering tanpa udara.

Beberapa penelitian sebelumnya banyak mengkaji potensi dari briket bioarang sebagai sumber energi alternatif, tapi belum banyak yang bisa menjawab pertanyaan mengapa industri bioarang belum berkembang dan pemanfaatannya dalam rumah tangga dan industri masih terbatas.Karena itu diperlukan kajian lebih lanjut mengenai kelebihan, kelemahan, peluang dan ancaman dari industri bioarang ini.

Untuk mendorong pemanfaatan biomassa dari limbah yang tidak termanfaatkan menjadi sesuatu yang bernilai ekonomis maka perlu dilakukan penelitian terkait potensi pemanfaatan biomassa sebagai alternatif sumber energi terbarukan yang ramah lingkungan.Beberapa penelitian selama ini lebih banyak membahas tentang potensi teknis pemanfaatan biomassa tetapi masih sedikit penelitian yang mengkaji tentang potensi ekonomis dan sosial pemanfaatan biomassa menjadi briket bio-arang.Tujuan dari penelitian ini adalah mengkaji potensi dan prioritas pengembangan produk briket bioarang dari biomassa sebagai sumber energi alternatif sehingga tergambar potensi keseluruhan dari pemanfaatan biomassa menjadi bio-arang.

\section{BAHAN DAN METODE}

Penelitian ini dilakukan dengan melakukan survei lapang pada CV. 'XYZ', sebuah usaha pembuatan arang dari kayu di Kota Dumai, Provinsi Riau. Pengumpulan data primer juga dilakukan dengan wawancara dengan respondenkonsumen arang dan briket di Kota Dumai. Pengumpulan data sekunder dilakukan dengan browsing internet ke beberapa sumber 
data, seperti Biro Pusat Statistik, Kementrian Energi dan Sumber Daya Manusia, Pertamina, dan lain-lain.Penelitian dilakukan pada Bulan September-Oktober 2020. Parameter yang diamati meliputi penyediaan bahan baku, proses produksi, proses pengujian kualitas, proses pengepakan dan proses penyimpanan. Parameter yang diukur meliputi jumlah produksi harian, kebutuhan bahan baku harian, jumlah produk yang dikemas, jumlah produk yang disimpan dan jumlah produk yang dikirim ke konsumen. Data yang diambil dari wawancara dengan bantuan kuisioner terbuka meliputi : 1) hambatan dalam proses produksi, 2) hambatan dalam penyediaan bahan baku, 3) hambatan dalam penyimpanan produk, 4) hambatan dalam pemasaran produk, 5) competitor, 6) kelebihan produk disbanding competitor, 7) kelemahan produk disbanding competitor, 8) ancaman dalam pengembangan usaha, dan 9) peluang dalam pengembangan usaha.

Kuesioner yang disebarkan sebanyak 13 buah kepada 12 pekerja dan 1 pemilik usaha, dan dikembalikan sebanyak 13 buah.

Analisis data dilakukan secara kuantitatif dengan menggunakan analisis SWOT (Strength, Weak, Opportunity dan Threat). Analisis SWOT diterapkan untuk melihat potensi pengembangan briket bioarang sebagai sumber energi alternatif sebagai pengganti penggunaan arang biasa.Analisis SWOT memiliki peran penting sebagai patokan untuk melihat posisi briket bioarang saat ini, sehingga kita bisa menyusun strategi untuk lebih memaksimalkan pemanfaatan briket bioarang sebagai sumber energi alternatif. Analisis SWOT memiliki dua komponen utama yaitu faktor internal sistem yang digambarkan sebagai kekuatan (Strength) dan kelemahan (Weakness) dan faktor eksternal sistem yang digambarkan sebagai peluang (Opportunity) dan ancaman (Threat) (Thaheer et al., 2011; Alkadri, 2014).

Faktor-faktor strategis internal adalah faktorfaktor yang berasal dari dalam perusahaan yang secara langsung dapat mempengaruhi proses produksi, kinerja dan arah pengembangan produk. Faktor ini meliputi kekuatan (Strength) dan kelemahan (weakness) dari produk briket bioarang dibandingkan arang biasa.
Pengumpulan data dilakukan dengan melakukan observasi dan wawancara terhadap pengelola perusahaan dan para pekerjanya, serta mengumpulkan data-data primer yang terkait jumlah produksi, jumlah penjualan, manajemen pemasaran dan strategi promosi (David, 2015)

Faktor-faktor strategis eksternal adalah faktorfaktor strategis yang berasal dari luar perusahaan tersebut, yang meliputi faktor peluang (Opportunity) dan ancaman (Threath). Analisis lingkungan faktor eksternal meliputi: 1) ekonomi, 2) masyarakat/sosial dan budaya/ demografi, 3) kepemerintahan atau politik, 4) ilmu dan teknologi, dan 5) persaingan (David, 2015).

Data SWOT kualitatif selanjutnya dianalisis secara kuantitatif melalui perhitungan analisis SWOT yang dikembangkan oleh Pearce dan Robinson (Pearce dan Robinson, 1998). Analisis dilakukan dengan tahapan sebagai berikut: (1) Melakukan perhitungan bobot tiap-tiap faktor dengan skala 1-0 (sangat penting- tidak penting). Pemberian rating skala untuk 4-1 untuk kekuatan yang terbesar hingga kekuatan terkecil serta rating skala 1-4 untuk kelemahan terbesar hingga kelemahan terkecil.Kemudian dilakukan perkalian antara bobot dengan rating sehingga didapatkan nilai untuk masing-masing faktor, (2) Menjumlahkan nilai dari masing-masing faktor sehingga didapatkan nilai total untuk faktor strategi internal dan eksternal, hitung selisih antara S-W dan O-T, (3) Menentukan posisi potensi pengembangan briket bio-arang pada kuadran SWOT.

\section{HASIL DAN PEMBAHASAN}

\subsection{Potensi Pengembangan Briket Bioarang di Indonesia}

Pemanfaatan batubara sebagai bahan bakar padat dari segi ekonomis dan lingkungan kurang direkomendasikan karena pembakaran batubara mengeluarkan fly ash yang tidak baik jika terhirup oleh manusia. Batu bara akan lebih bermanfaat jika diolah jadi bahan bakar cair pengganti bensin dan solar. Demikian juga menggunakan kayu dan biomassa lain sebagai bahan bakar padat juga kurang baik untuk lingkungan. Sehingga potensi briket bioarang 
sebagai pengganti batu bara dan arang cukup besar karena: (1). Tidak/sedikit mengeluarkan asap saat dibakar, (2).Terbuat dari bahan yang bisa diperbarui (renewable), (3). Lebih hemat, dengan jumlah bahan baku yang sama bisa menghasilkan briket lebih banyak dibandingkan jika dibuat arang biasa.

\subsection{Faktor Internal}

Faktor Internal dalam analisis SWOT merupakan faktor yang mengidentifikasikan kekuatan atau keunggulan-keunggulan dan kelemahankelemahan yang dapat digunakan pada pengembangan industri briket bioarang di tanah air. Hasil penelitian ini menunjukkan terdapat beberapa kekuatan (strength) untuk mengembangkan industri briket bioarang antara lain : 1) bahan baku tersedia terus menerus dan bisa diperbarui (renewable dan sustainable). Bahan baku yang digunakan tersedia secara lokal dan relatif mudah didapatkan, 2) bahan baku murah dan melimpah (cheap and abundant), 4) bioarang bisa dibuat dari biomassa yang berbeda-beda seperti limbah kayu, batok kelapa, cangkang sawit, bamboo, dan sebagainya. Bahan

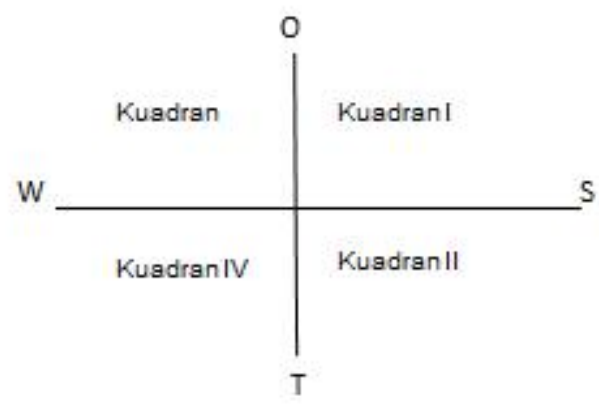

baku tersebut umumnya selama ini masih dianggap sebagai limbah yang tidak dimanfaatkan, 3) produk lebih ramah lingkungan karena pada saat pembakaran tidak/ sedikit menghasilkan asap dibandingkan pembakaran batu bara dan arang biasa, 4) proses pendistribusian lebih mudah karena dimensi dan volumenya relatif lebih kecil dan teratur (Gambar 2) sehingga bisa muat lebih banyak dalam satu kali pengangkutan, 5) teknologi sederhana dan mudah dipelajari sehingga bisa digunakan oleh masyarakat awam.

Disamping kekuatan dari faktor internal, hasil penelitian ini juga mengungkapkan beberapa kelemahan (weakness) dalam pengembangan industri briket bioarang antara lain: 1) produk briket bioarang masih kurang popular dikalangan pengusaha dan masyarakat, 2) kalor pembakaran masih fluktuatif tergantung bahan baku yang digunakan, 3) briket bioarang membutuhkan tungku pembakaran yang dianggap kurang aman bagi ibu rumah tangga, seperti yang terlihat di Gambar 3.

Kuadran I (positif, positif). Posisi ini menandakan potensi briket bio-arang sebagai sumber energi alternatif kuat dan berpeluang

Kuadran II (positif, negatif). Posisi ini menandakan potensi briket bio-arang sebagai sumber energi alternatif cukup besar namun juga menghadapi tantangan yang besar

Kuadran III (negatif, positif). Posisi ini menandakan potensi briket bio-arang sebagai sumber energi alternatif sangat lemah namun berpeluang

Kuadran IV (negatif, negatif). Posisi ini menandakan potensi briket bio-arang sebagai sumber energi alternatif sangat lemah dan menghad api tantangan yang besar

Gambar 1. Kuadran SWOT

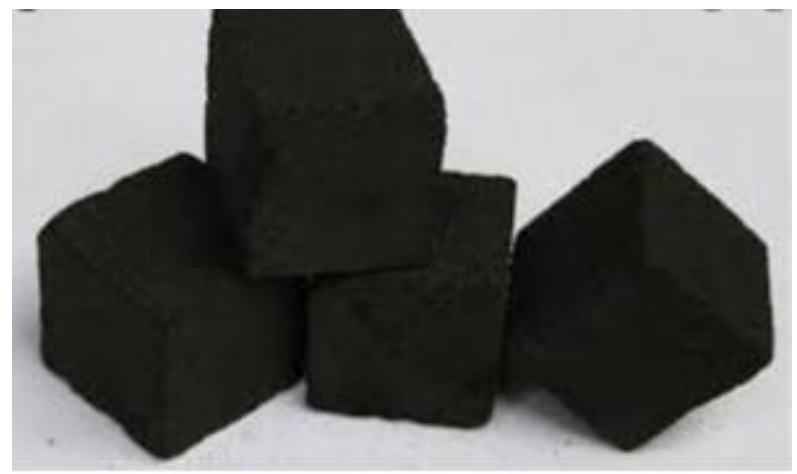

Gambar 2. Briket Bio-arang yang Dihasilkan 


\subsection{Faktor Eksternal}

Faktor eksternal dalam analisis SWOT merupakan faktor yang mengidentifikasikan peluang dan ancaman yang yang dihadapi pada pengembangan industri briket bioarang.Hasil penelitian ini menunjukkan terdapat beberapa peluang (opportunity) untuk mengembangkan industri briket bioarang antara lain : 1) kesadaran masyarakat terhadap keselamatan dan kelestarian lingkungan semakin tinggi, sehingga produk yang lebih ramah lingkungan akan lebih disukai, 2) anjuran peneliti untuk mengkomersilkan batu bara sebagai bahan bakar cair akan membuka peluang briket bioarang sebagai bahan bakar pengganti batu bara, 3) mendapat dukungan politik yang kuat dari pemerintah

Hasil analisis faktor eksternal juga mengungkapkan beberapa ancaman (threath) yang dihadapi bagi pengembangan industri briket bioarang antara lain: 1) perubahan kebijakan terkait energi alternatif kurang mendapat apresiasi dari masyarakat. Kebijakan penggantian sumber energi ini biasanya kurang popular dan membutuhkan waktu dan usaha untuk membiasakan masyarakat terhadap perubahan, 2) bahan bakar padat kurang popular dikalangan rumah tangga karena dianggap kotor dan kurang aman.

Berdasarkan hasil analisis faktor internal dan faktor eksternal tersebut, maka didapatkan tabel analisis SWOT dalam Tabel 1. Berdasarkan hasil Tabel 1 maka selanjutnya dilakukan analisis kuantitatif terhadap data SWOT. Hasil matrik IFAS didapatkan nilai 3.25.Nilai bobot untuk setiap faktor internal terlihat pada Tabel 2. Analisis kuantitatif terhadap data SWOT untuk perhitungan nilai bobot untuk setiap faktor eksternal didapatkan hasil 2.75 dengan rincian pada Tabel 3.

Matrik IFAS dan matrik EFAS menunjukkan bahwa total nilai IFAS sebesar 3.25 dan total nilai EFAS sebesar 2.75. Selisih antara kekuatan dengan kelemahan bernilai positif yakni 2.29 dan selisih antara peluang dengan ancaman juga bernilai positif yakni 1.55 . Hasil ini kemudian bila digambarkan pada kuadran SWOT maka berada dalam posisi kuadran I (positif, positif).Posisi ini menandakan bahwa potensi briket bio-arang sebagai sumber energi alternatif adalah kuat dan berpeluang.

Potensi briket bio-arang sebagai sumber energi alternatif sangat kuat karena bahan bakuyang digunakan untuk membuat briket bioarang tersedia terus menerus dan bisa diperbarui (renewable dan sustainable). Bio-arang bisa dibuat dengan menggunakan berbagai jenis bahan baku yang berasal dari biomassa yang harganya murah dan melimpah (cheap and abundant) seperti cangkang sawit, batok kelapa, limbah kayu, kotoran sapi, sampah organik dan limbah pertanian/perkebunan lainnya.Dengan demikian bio-arang bisa menjadi alternatif untuk menggantikan penggunaan energi fossil yang makin menipis ketersediaannya.Menurut Eka Putri dan Andasuryani (2017) biomassa merupakan sumber energi utama ketiga terbesar di dunia, setelah minyak dan batubara.Pemanfaatan biomassa sebagai bahan bakar alternatif pengganti bahan bakar fosil merupakan salah satu pilihanpengembangan mekanisme bersih (clean development mechanism, CDM) untuk mengurangi emisikarbon ke atmosfer.

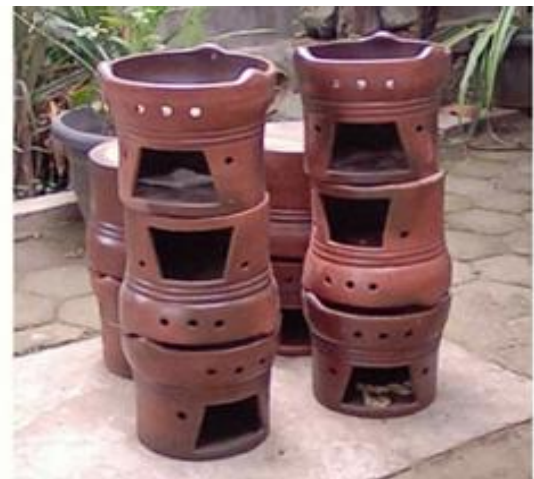

Gambar 3. Tungku Pembakaran Bioarang Skala Rumah Tangga 
Tabel 1. Matrik Analisis SWOT

\begin{tabular}{|c|c|c|}
\hline $\begin{array}{l}\text { Faktor Internal dan } \\
\text { Faktor Eksternal }\end{array}$ & $\begin{array}{l}\text { Kekuatan } \\
\text { (strength) } \\
\text { 1. } \quad \text { Renewable } \\
\text { 2. } \text { Bahan baku murah } \\
\text { 3. Ramah lingkungan } \\
\text { 4. } \\
\text { 5istribusi mudah } \\
\text { Teknologi sederhana }\end{array}$ & $\begin{array}{l}\text { Kelemahan } \\
\text { (weakness) } \\
\text { 1. Kurang popular } \\
\text { 2. Kalor pembakaran } \\
\text { fluktuatif } \\
\text { 3. Butuh tungku } \\
\text { pembakaran }\end{array}$ \\
\hline $\begin{array}{l}\text { Peluang (Opportunity) } \\
\text { 1.Kesadaran lingkungan } \\
\text { masyarakat tinggi } \\
\text { 2.Pengganti batu bara } \\
\text { 3.Dukungan } \\
\text { pemerintah }\end{array}$ & $\begin{array}{l}\text { S-O } \\
\text { Menggunakan kekuatan untuk } \\
\text { memanfaatkan peluang }\end{array}$ & $\begin{array}{l}\text { W-O } \\
\text { Meminimalkan } \\
\text { kelemahan untuk } \\
\text { memanfaatkan peluang }\end{array}$ \\
\hline $\begin{array}{l}\text { Ancaman }(\text { Threath }) \\
\text { 1.Apresiasi masyarakat } \\
\text { terhadap energi } \\
\text { alternative masih } \\
\text { rendah } \\
\text { 2.Bahan bakar padat } \\
\text { kurang popular di } \\
\text { masyarakat }\end{array}$ & $\begin{array}{l}\text { S-T } \\
\text { Menggunakan kekuatan untuk } \\
\text { mengatasi ancaman }\end{array}$ & $\begin{array}{l}\text { W-T } \\
\text { Meminimalkan } \\
\text { kelemahan dan } \\
\text { menghindari ancaman }\end{array}$ \\
\hline
\end{tabular}

Tabel 2. Matrik IFAS (Internal Factor Analysis Summary)

\begin{tabular}{clccc}
\hline No & \multicolumn{1}{c}{ Faktor } & Bobot & Rating & Skor \\
\hline 1 & Kekuatan & & & \\
& 1.Renewable & 0.20 & 4 & 0.80 \\
& 2.Bahan baku murah & 0.18 & 4 & 0.72 \\
& 3.Ramah lingkungan & 0.15 & 3 & 0.45 \\
& 4.Distribusi mudah & 0.10 & 2 & 0.20 \\
& 5.Teknologi sederhana & 0.15 & 4 & 0.60 \\
\hline 2 & Kelemahan & 0.10 & 2 & 0.20 \\
& 1.Kurang popular & 0.08 & 2 & 0.16 \\
& 2.Kalor pembakaran fluktuatif & 0.04 & 3 & 0.12 \\
\hline & 3.Butuh tungku pembakaran & 1.00 & & 3.25 \\
\hline
\end{tabular}

Tabel 3. Matrik EFAS (External Factor Analysis Summary)

\begin{tabular}{clccc}
\hline No. & \multicolumn{1}{c}{ Faktor } & Bobot & Rating & Skor \\
\hline 1 & $\begin{array}{l}\text { Peluang } \\
\text { 1.Kesadaran lingkungan makin }\end{array}$ & 0.30 & 4 & 1.20 \\
& $\begin{array}{l}\text { tinggi } \\
\text { 2.Pengganti batu bara }\end{array}$ & 0.15 & 3 & 0.45 \\
& $\begin{array}{l}\text { 3.Dukungan pemerintah } \\
\text { Ancaman }\end{array}$ & 0.25 & 2 & 0.50 \\
\hline & $\begin{array}{l}\text { 1.Apresiasi masyarakat rendah } \\
\text { 2.Bahan bakar padat kurang } \\
\text { popular }\end{array}$ & 0.15 & 2 & 0.30 \\
& \multicolumn{1}{c}{ Total } & 2 & 0.30 \\
\hline
\end{tabular}


Pemanfaatan bahan baku yang berasal dari biomassa menjadi bioarang juga bersifat ramah lingkungan karena selama ini bahan baku tersebut cenderung belum dimanfaatkan secara optimal oleh petani atau masyarakat dan belum memiliki nilai ekonomis yang tinggi. Pada saat digunakan, briket bio-arang ini juga lebih ramah lingkungan karena mengeluarkan asap pembakaran yang relatif lebih rendah dibandingkan arang biasa, sehingga bagi masyarakat ekonomi lemah yang tinggal di kotakota dengan ventilasi perumahannya kurang mencukupi, sangat praktis menggunakan briket bioarang.

Penggunaan briket bio-arang juga memiliki panas yang lebih tinggi dan dapat menyala dalam waktu yang lama bila dibandingkan arang kayu, tidak berbau dan memiliki aroma alami yang khas. Panas yang dihasilkan oleh briket bioarang lebih tinggi dibandingkan dengan kayu biasa yakni nilai kalor yang mencapai 5.000 kalori/ gram, lebih tinggi dibandingkan kayu (kering mutlak) 4.491,2 kal/g dan batu bara muda (lignit) $1.887,3 \mathrm{kal} / \mathrm{g}$. Setelah briket bioarang terbakar (menjadi bara) juga tidak perlu dilakukan pengipasan atau diberi udara.Namun dalam penggunaannya briket bio-arang membutuhkan tungku pembakaran yang bagi sebagian masyarakat sering dianggap kuno/tradisional.

Pembuatan briket bio-arang ini dapat dilakukan dengan menggunakan teknologi yang sederhana sehingga mudah dipelajari dan diadopsi oleh masyarakat.Bagi sebagian daerah di Indonesia yang masih sulit terjangkau sarana transportasi dalam proses pendistribusian bahan bakar, maka penggunaan briket bio-arang sangat membantu sebagai alternatif sumber bahan bakar yang dapat diperbarui dan bermanfaat untuk masyarakat. Teknologi pembuatan briket bioarang juga tidak memerlukan bahan kimia lain kecuali yang terdapat dalam bahan briket itu sendiri.

Dari sisi eksternal, saat ini pemerintah juga sedang giat melakukan optimalisasi pemanfaatan biomassa untuk mengganti batubara. Pemerintah tengah mengupayakan adanya terobosan pemanfaatan biomassa guna mengurangi peran batubara yang masih dominan secara nasional dan mendorong capaian target Bauran Energi baru dan Terbarukan (EBT) pada tahun 2025. Bauran EBT mencapai 9,15\% sampai akhir tahun 2019, 6,2\% bersumber dari PLT EBT dan 2,95\% bersumber dari Bahan Bakar Nabati jenis biodesel. Pada tahun 2025, ditargetkan bauran EBT 23\%. PLT EBT ditargetkan menyumbang bagian bauran sebanyak 13\%-15\%, PLT Bioenergi 2\%-5\%, dan biodiesel 2\%-3\%. Sekarang ini pemerintah tengah mengusahakan pelaksanaan program Tungku Sehat Hemat Energi (TSHE). TSHE ini adalah bagian dari kerjasama pemerintah dengan Bank Dunia yakni clean stove initiative. Program ini dimaksudkanuntuk penganekaragaman sumber energi terbarukan untuk kebutuhan harian Rumah Tangga dan Kelompok Usaha Kecil Menengah (KUKM), dengan memanfaatkan potensi biomasa yang besar. Tujuan jangka panjangnya, diharapkan bisa meminimalkan subsidi bahan bakar gas yang semakin meningkat (Diretorat Jenderal EBTKE, 2021).

\section{KESIMPULAN}

Dari hasil penelitian yang dilakukan di industri pembuatan arang kayu di Kota Dumai, Provinsi Riau dapat disimpulkan bahwa potensi pengembangan produk briket bioarang dari biomassa sebagai sumber energi alternatif adalah kuat dan berpeluang. Hal ini didasarkan pada hasil analisis matrik IFAS yang bernilai positif (3.25) dan matrik EFAS yang juga positif (2.75), Hasil analisis kuadran SWOT menunjukkan bahwa potensi pengembangan produk briket bioarang dari bio-massa berada pada kuadran I yakni total nilai kekuatan lebih besar dibandingkan total nilai kelemahan dan total nilai peluang juga lebih besar dibandingkan total nilai ancaman. Hasil penelitian ini merekomendasikan perlunya public policy terkait promosi dan sosialisasi penggunaan briket bioarang sebagai salah satu sumber energi bersih yang ekonomis dan ramah lingkungan

\section{DAFTAR PUSTAKA}

Alkadri, A. 2014. Analisis Nilai Tambah dan Strategi Pengembangan Usaha Kerajinan Kepek Rotan: Studi Kasus di Desa Nusawungu Kabupaten Cilacap. [Skripsi]. Institut Pertanian Bogor. 
Arni, A., Labania, H.M., dan Nismayanti, A. 2014. Studi Uji Karakteristik Fisis Briket Bioarang Sebagai Sumber Energi Alternatif. Natural Science: Jurnal of Science and Technology, 3(1): 89-98.

David, F.R. 2015. Strategic Management: Concepts and Cases. Pearson Education, Inc., Upper Saddle River, New Jersey, USA.

Diretorat Jenderal EBTKE. 2021. Transisi Energi, Kementerian ESDM Jalin Kerja Sama Program Peningkatan Akses Energi Bersih dan Berkelanjutan. Siaran Pers. 8 Maret 2021. https://ebtke.esdm.go.id/post/ $20021 / 03 / 08 / 2819$ / transisi.energikementerian.esdm.jalin.kerja.sama. program.peningkatan.akses.energi.bersih.dan. berkelanjutan.

Febrina, W. 2018. Potensi Sampah Organik Sebagai Bahan Baku Pembuatan Briket Bio Arang. Unitek, 11(1): 40-50.

Kalsum, U. 2016. Pembuatan Briket dari Campuran Limbah Tongkol Jagung, Kulit Durian dan Serbuk Gergaji Menggunakan Perekat Tapioka. Distilasi, 1(1): 42-50.

Miharja, M. 2016. Analisis proksimat potensi briket bioarang sebagai energi alternatif di desa kusu, Maluku Utara. Jurnal Techno, 5(1): 15-21.

Pearce, J.A dan Robinson, R. 2008. Manajemen stretegis: Formulai, Implementasi, dan Pengendalian. Edisi kesepuluh. PT Salemba Empat, Jakarta.

Putri, E.R. dan Andasuryani, A. 2017. Studi Mutu Briket Arang Dengan Bahan Baku Limbah Biomassa. Jurnal Teknologi Pertanian Andalas, 21(2): 143-151. https://doi.org/ 10.25077/jtpa.21.2.143-151.2017

Santosa, Mislaini, R., dan Anugrah, S.P. 2010. Studi Variasi Komposisi Bahan Penyusun Briket Dari Kotoran Sapi Dan Limbah Pertanian. Jurnal Teknik Pertanian, 1-26.

Surest, A. H. dan Afif, H. 2011. Pembuatan Briket Arang dari Serbuk Gergaji Kayu dan Tempurung Kelapa Dengan Proses Karbonisasi. Jurnal Teknik Kimia, 17(8): 29-40.

Thaheer, H., Hasibuan, S., dan Ma'ruf, A. 2011. Kajian Strategi Pengembangan Investasi Energi Alternatif Di Indonesia. Warta Kebijakan Iptek \& Manajemen Litbang, 9(1): 41-58. 